IFAS Extension

\title{
Powdery Mildew of Strawberries ${ }^{1}$
}

\author{
N. A. Peres and J. C. Mertely ${ }^{2}$
}

Powdery mildew, Podosphaera aphanis (syn. Sphaerotheca macularis), occurs in most areas of the world where strawberries are grown.

\section{Pathogen and Symptoms}

P. aphanis infects leaves, flowers, and fruit. Early foliar infections are characterized by small white patches of fungus growing on the lower leaf surface. On susceptible cultivars, dense mycelial growth and numerous chains of conidia (spores) give these patches a powdery appearance (Figure 1). Under favorable conditions, the patches expand

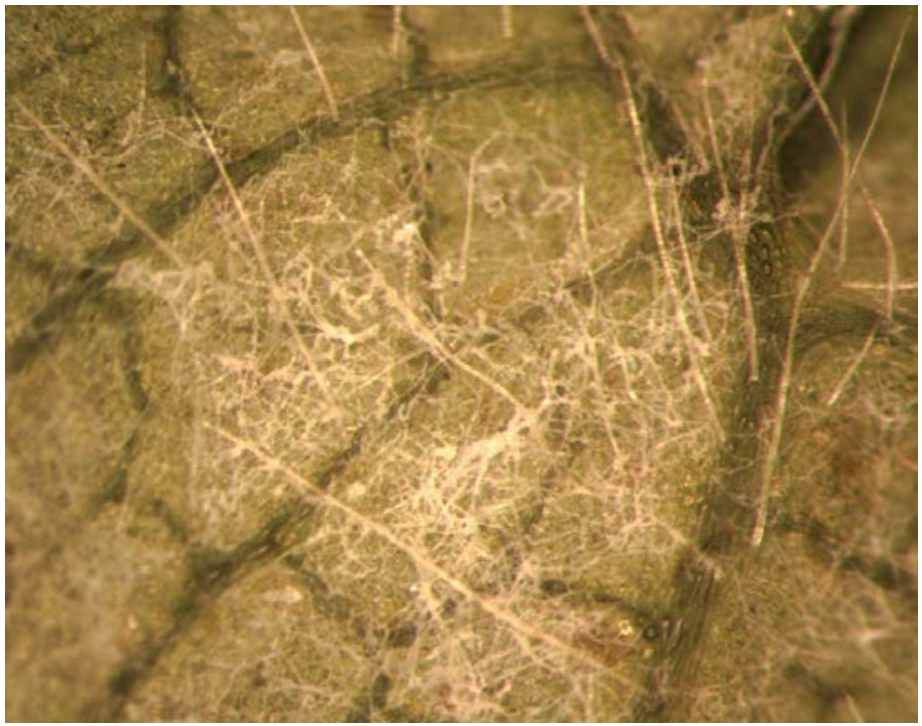

Figure 1. Podosphaera aphanis mycelia on strawberry leaf surface Credits: UF, GCREC and coalesce until the entire lower surface of the leaf is covered (Figure 2). In some strawberry cultivars, relatively little mycelium is produced, making it difficult to see the white patches. Instead, irregular yellow or reddish-brown spots develop on colonized areas on the lower leaf surface and eventually break through to the upper surface (Figure 3). The edges of heavily infected leaves curl upward (Figure 4). At times, dark round structures (cleistothecia) are produced in the mycelia on the undersides of leaves (Figure 5). Cleistothecia are initially white but turn black

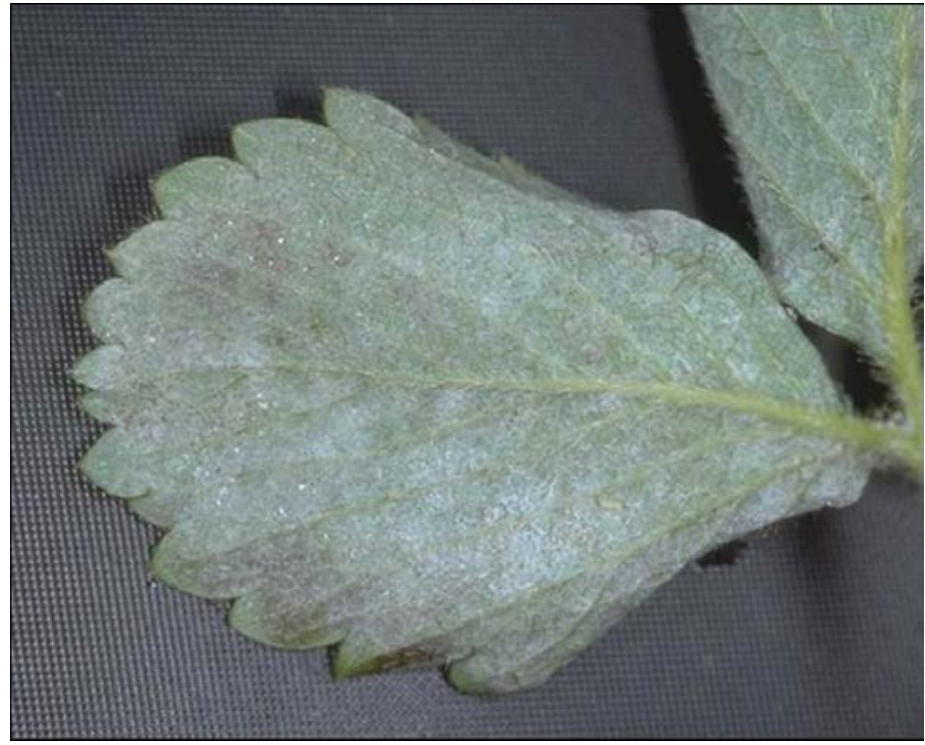

Figure 2. Lower leaf surface of strawberry covered with powdery mildew

Credits: UF, GCREC

1. This document is PP-208, one of a series of the Plant Pathology Department, Florida Cooperative Extension Service, Institute of Food and Agricultural Sciences, University of Florida. Original publication date January 2004. Revised May 2013. Visit the EDIS website at http://edis.ifas.ufl.edu.

2. N. A. Peres, associate professor, Plant Pathology Department, and J. C. Mertely, coordinator programs/services, Gulf Coast Research and Education Center--Wimauma, FL; Florida Cooperative Extension Service, Institute of Food and Agricultural Sciences, University of Florida, Gainesville, FL 32611.

The use of trade names in this publication is solely for the purpose of providing specific information. UF/IFAS does not guarantee or warranty the products named, and references to them in this publication does not signify our approval to the exclusion of other products of suitable composition. 
as they mature. The fungus also infects flowers, which may produce aborted or malformed fruit. In addition, $P$. aphanis colonizes older fruit, producing a fuzzy mycelial growth on the seeds (Figure 6). Both types of infection may reduce fruit quality and marketable yields.

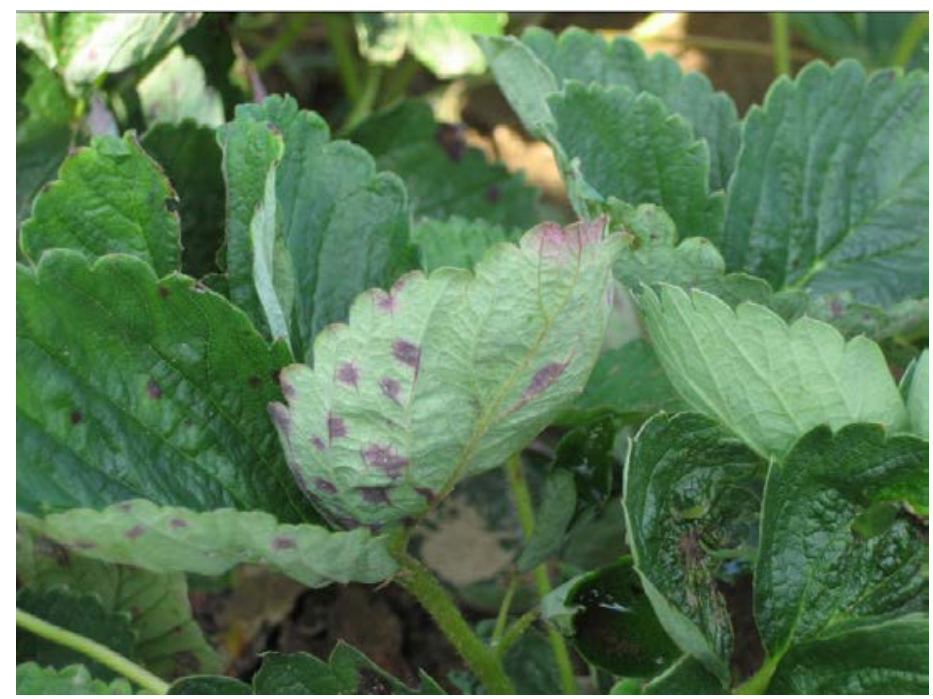

Figure 3. Reddish-brown spot reaction caused by Podosphaera aphanis in some cultivars

Credits: UF, GCREC

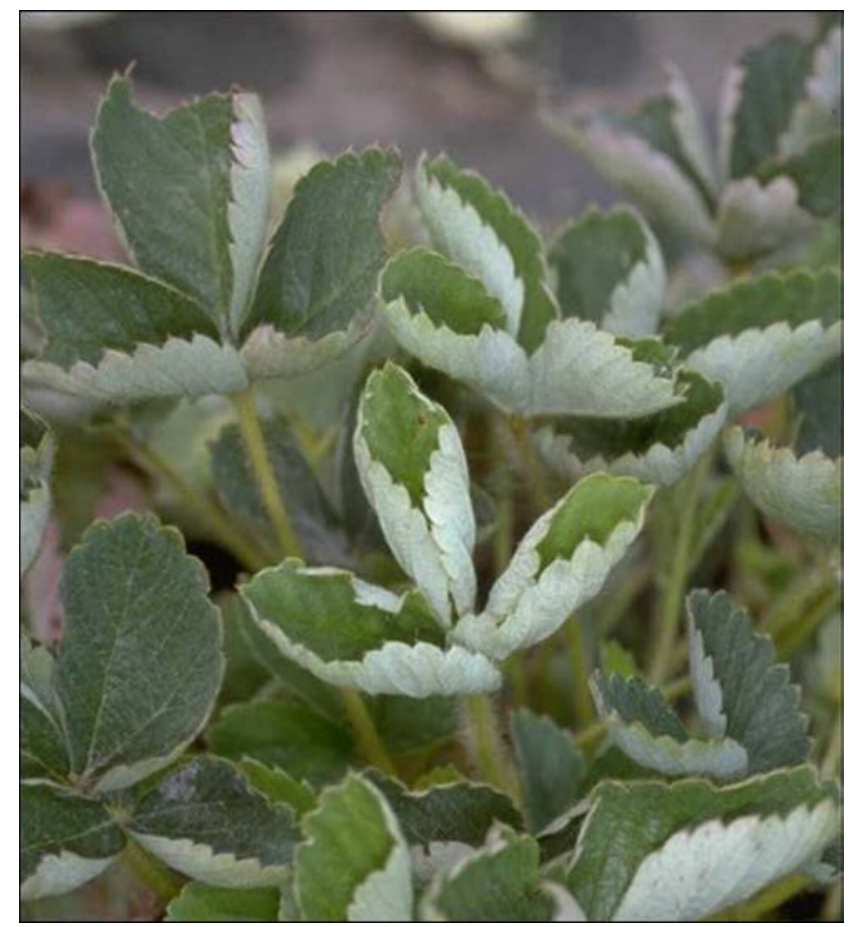

Figure 4. Curling leaves on plants severely infected with powdery mildew

Credits: UF, GCREC

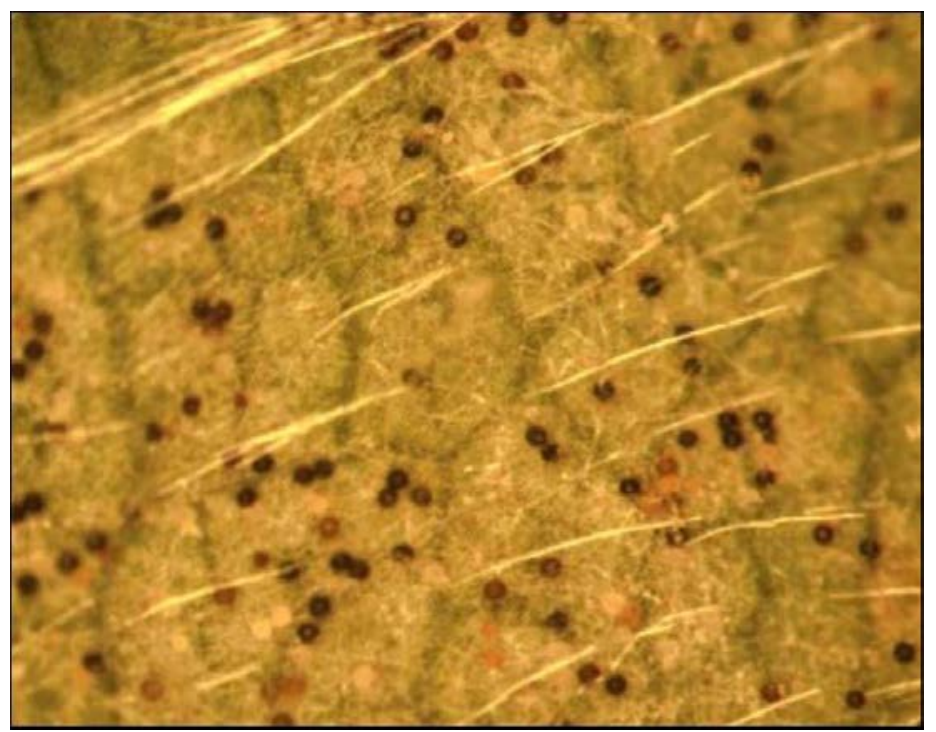

Figure 5. Micrograph of Podosphaera aphanis cleistothecia on leaf surface

Credits: UF, GCREC

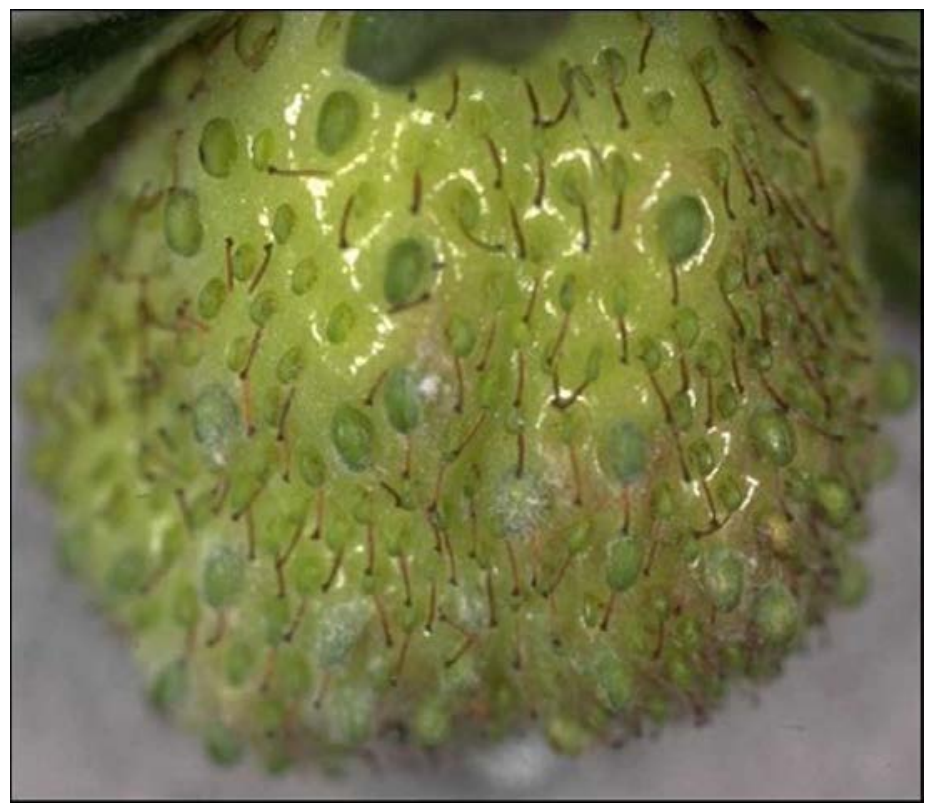

Figure 6. Podosphaera aphanis on strawberry achenes

Credits: UF, GCREC 


\section{Disease Development and Spread}

P. aphanis is an obligate parasite that only infects living tissue of wild or cultivated strawberry. The fungus readily infects living, green leaves in the nursery. Thus, infected transplants are normally the primary source of inoculum for fruiting fields in Florida. When conditions are favorable, conidia produced on infected plants are wind dispersed. Powdery mildew development and spread are favored by moderate to high humidity and temperatures between $60^{\circ} \mathrm{F}$ and $80^{\circ} \mathrm{F}$. Rain, dew, and overhead irrigation inhibit the fungus. Because dry conditions and high humidity are common in greenhouses and plastic tunnels, powdery mildew is typically more severe in protected culture. In open fields in Central Florida, the disease is typically most severe in November and December, usually subsides in January and early February, and may reappear in late February and March.

\section{Control}

Using powdery mildew-free transplants is a good method to control the disease, but even disease-free fields can become infected by conidia blown in from neighboring fields. Cultivars differ in their resistance to powdery mildew. However, the two most popular cultivars, 'Strawberry Festival' and 'Florida Radiance', are susceptible to the disease. Fields with susceptible cultivars should be surveyed regularly for powdery mildew, especially early in the season. Fungicides should be applied preventively or at the first sign of disease to control powdery mildew on susceptible cultivars. This is especially important when using protectant fungicides, such as elemental sulfur. Systemic fungicides have some limited curative action. These include Rally ${ }^{\oplus}$ (active ingredient myclobutanil), which was formerly named Nova ${ }^{\circledR}$; Procure ${ }^{\circledast}$ (active ingredient triflumizole);

Orbit $^{\oplus}$ (active ingredient propiconazole); and Mettle (active ingredient tetraconazole). These products are treated as a group since they belong to the same fungicide class and have similar properties. They have a single mode of action and, for this reason, should be rotated with other fungicides with different properties to avoid the development of resistance. Quintec ${ }^{\circledR}$ and Torino ${ }^{\circledR}$ are newer, highly effective fungicides and have a mode of action different from other powdery mildew products. Other rotational options include Pristine $^{\circledast}$ (pyraclostrobin + boscalid) and Fontelis ${ }^{\mathrm{TM}}$ (penthiopyrad), but be careful not to exceed four applications of these products per season. Usually, controlling foliar infection helps to prevent fruit infection. 
Table 1. Fungicides recommended for control of powdery mildew of strawberries in Florida

\begin{tabular}{|c|c|c|c|c|c|}
\hline \multirow[t]{2}{*}{$\begin{array}{c}\text { Product name } \\
\text { (active ingredient) }\end{array}$} & \multirow[t]{2}{*}{$\begin{array}{l}\text { Fungicide } \\
\text { group }^{\mathrm{a}}\end{array}$} & \multicolumn{2}{|c|}{$\begin{array}{c}\text { Maximum rate per acre } \\
\text { per }\end{array}$} & \multirow[t]{2}{*}{$\begin{array}{l}\text { Min. days } \\
\text { to harvest }\end{array}$} & \multirow[t]{2}{*}{ Remarks } \\
\hline & & Application & Season & & \\
\hline $\begin{array}{c}\text { (Sulphur) } \\
\text { Many brands }\end{array}$ & M2 & Varies & Varies & 1 & $\begin{array}{l}\text { Do not use when temperatures exceed } \\
85^{\circ} \mathrm{F}\end{array}$ \\
\hline $\begin{array}{l}\text { Rally }^{\circledR} 40 \text { WSP } \\
\text { Nova }^{\circledR} 40 \text { W } \\
\text { Sonoma }{ }^{\circledast} 40 \text { WSP } \\
\text { (Myclobutanil) }\end{array}$ & 3 & $5 \mathrm{oz}$. & $30 \mathrm{oz}$ & 0 & $\begin{array}{l}\text { Do not plant rotational crops until } 30 \\
\text { days after last application }\end{array}$ \\
\hline $\begin{array}{c}\text { Orbit }^{\circledast} \\
\text { Tilt }^{\circledast} \\
\text { Bumper }^{\circledast} 41.8 \mathrm{EC} \\
\text { (Propiconazole) }\end{array}$ & 3 & 4 fl. oz. & 16 fl. oz. & 0 & $\begin{array}{l}\text { Do not make more than two } \\
\text { consecutive applications }\end{array}$ \\
\hline $\begin{array}{l}\text { Procure }^{\oplus} 50 \text { WS } \\
\text { (Triflumizole) }\end{array}$ & 3 & $8 \mathrm{oz}$ & $32 \mathrm{oz}$ & 1 & $\begin{array}{l}\text { Do not plant leafy vegetables within } 30 \\
\text { days, root vegetables within } 60 \text { days, or } \\
\text { rotational crops not on label for } 1 \text { year } \\
\text { after application }\end{array}$ \\
\hline $\begin{array}{l}\text { Mettle }^{\circledR} 125 \mathrm{ME} \\
\text { (Tetraconazole) }\end{array}$ & 3 & 5 fl. oz. & 20 fl. oz. & 0 & $\begin{array}{l}\text { Do not apply same product within } \\
14 \text { days; do not make more than four } \\
\text { applications per season }\end{array}$ \\
\hline $\begin{array}{l}\text { Quadris Top }^{\circledR} \\
\text { (Difenoconazole + } \\
\text { azoxystrobin) }\end{array}$ & $3+11$ & 14 fl. oz. & 56 fl. oz. & 0 & $\begin{array}{l}\text { Do not make more than two sequential } \\
\text { applications before alternating to } \\
\text { another fungicide group; make no } \\
\text { more than four applications/crop }\end{array}$ \\
\hline $\begin{array}{l}\text { Quilt Xcel } \\
\text { (Propiconazole + } \\
\text { azoxystrobin) }\end{array}$ & $3+11$ & 14 fl. oz. & 56 fl. oz. & 0 & $\begin{array}{l}\text { Do not make more than two } \\
\text { consecutive applications and no more } \\
\text { than four applications/crop }\end{array}$ \\
\hline $\begin{array}{c}\text { Fontelis }^{\mathrm{TM}} \\
\text { (Penthiopyrad) }\end{array}$ & 7 & 24 fl. oz. & 72 fl. oz. & 0 & $\begin{array}{l}\text { Do not make more than two sequential } \\
\text { applications before alternating to a } \\
\text { fungicide from a different group }\end{array}$ \\
\hline $\begin{array}{c}\text { Pristine }^{\circledast} \\
\text { (Boscalid + pyraclostrobin) }\end{array}$ & $7+11$ & $23 \mathrm{oz}$ & 115 oz. & 0 & $\begin{array}{l}\text { Do not make more than two } \\
\text { consecutive applications and no more } \\
\text { than five applications/crop }\end{array}$ \\
\hline $\begin{array}{l}\text { Quintec }^{\circledast} \\
\text { (Quinoxyfen) }\end{array}$ & 13 & 6 fl. oz. & 24 fl. oz. & 1 & $\begin{array}{l}\text { Do not make more than two } \\
\text { consecutive applications or more than } \\
\text { four applications per crop; do not plant } \\
\text { crops not on label for } 30 \text { days after } \\
\text { application }\end{array}$ \\
\hline $\begin{array}{l}\text { Torino }^{\circledR} \\
\text { (Cyflufenamid) }\end{array}$ & U6 & $3.4 \mathrm{oz}$ & $6.8 \mathrm{oz}$. & 0 & $\begin{array}{l}\text { Do not make more than two } \\
\text { applications per year; do not apply } \\
\text { more than once every } 14 \text { days }\end{array}$ \\
\hline \multicolumn{6}{|c|}{$\begin{array}{l}{ }^{a} \text { Fungicide group (FRAC Code): Numbers (1-37) and letters (M) are used to distinguish the fungicide mode of action groups. All fungicides } \\
\text { within the same group (with same number or letter) indicate same active ingredient or similar mode of action. This information must be } \\
\text { considered when making decisions about how to manage fungicide resistance. } M=\text { multisite inhibitors; fungicide resistance risk is low. Source: } \\
\text { http://www.frac.info/ (FRAC = Fungicide Resistance Action Committee). } \\
{ }^{b} \text { For example, Kumulus }{ }^{\oplus} \text { DF, Micro Sulf }{ }^{\oplus} \text {, Microfine Sulfur, Microthiol }{ }^{\oplus} \text { Disperss }{ }^{\oplus} \text {, Sulfur } 90 W \text {, Wettable Sulfur, Wettable Sulfur } 92 \text {, Yellow Jacket } \\
\text { Dusting Sulfur, Yellow Jacket Wettable Sulfur } \\
\text { Always read a current product label before applying any chemicals. }\end{array}$} \\
\hline
\end{tabular}

